\title{
Wybory do Parlamentu Europejskiego w Niemczech (25.05.2014) - analiza i następstwa
}

W dniach 22-25 maja 2014 r. w 28 państwach członkowskich Unii Europejskiej przeprowadzone zostały wybory do Parlamentu Europejskiego. W Republice Federalnej Niemiec - podobnie jak w Polsce i większości państw członkowskich Unii Europejskiej - wybory odbyły się 25 maja i były one dla Niemców ósmą elekcją kandydatów do PE (pierwsza odbyła się w 1979 r.). Wybory w Niemczech były obserwowane z wielkim zainteresowaniem w całej Europie nie tylko ze względu na liczbę ludności, pozycję RFN w Unii Europejskiej i wielkość niemieckiej reprezentacji w Parlamencie Europejskim (96 spośród 751 posłów do Parlamentu Europejskiego VIII kadencji pochodzi z Niemiec), ale również ze względu na rolę Niemiec w ratowaniu pogrążonych w kryzysie gospodarek państw strefy euro będących członkami Unii Europejskiej. Kwestia konsensusu głównych sił politycznych RFN na rzecz wspierania pogrążonych w kryzysie państw południowej Europy i uchwalanie przez Bundestag w latach 2010-2013 kolejnych pakietów pomocowych (Koszel, 2011, s. 118-127) stała się przedmiotem ogólnoniemieckiej debaty politycznej, a wspierany przez główne siły polityczne kurs pomocowy legł u źródeł powołania do życia w lutym 2013 r. nowego ugrupowania Alternatywa dla Niemiec (Alternative für Deutschland, AfD), skupiającego przeciwników kursu pomocowego, eurosceptyków różnej proweniencji oraz zwolenników przywrócenia w przyszłości niemieckiej marki. Wybory do Parlamentu Europejskiego były pierwszą poważną próbą sił dla niemieckich partii politycznych od czasu wyborów do Bundestagu z 22 września 2013 r., które doprowadziły do znacznych przeobrażeń na niemieckiej scenie politycznej (utrata znaczenia FDP, pojawienie się AfD) i powołania rządu wielkiej koalicji CDU/CSU-FDP kanclerz Angeli Merkel. Niemieckie wybory do Parlamentu Europejskiego z 25 maja 2014 r. były wyjątkowe jeszcze z jednego powodu: po raz pierwszy zrezygnowano w nich ze stosowania progu wyborczego (tzw. klauzuli zaporowej, Sperrklausel) ustalonego wcześniej na poziomie $5 \%$. W poniższej analizie podjęta zostanie próba odpowiedzi na kilka istotnych pytań badawczych: 1) czy zniesienie progu wyborczego miało wpływ na skład reprezentacji niemieckiej do Parlamentu Europejskiego i czy wpłynęło na wzrost poparcia dla niewielkich partii, niemających wcześniej szans na przekroczenie granicy progu wyborczego?; 2) jakie zmiany nastapiły w porównaniu do poprzednich wyborów do Parlamentu Europejskiego z 2009 r.?; 3) czy utrwalony został trend wyznaczony przez wybory do Bundestagu z 22 września 2013 r. polegający na utracie poparcia przez FDP i wzroście zaufania do AfD?; 4) czy Niemcy opowiedzieli się za kontynuowaniem dotychczasowego kursu w polityce europejskiej reprezentowanego przez główne siły polityczne?; 5) jak wyniki niemieckich wyborów prezentowały się na tle wyników 
z innych państw Unii Europejskiej? Prezentowany artykuł składa się z czterech części. W pierwszej naszkicowana została ordynacja wyborcza i wyjaśnione przyczyny zniesienia progu wyborczego. Druga część poświęcona została omówieniu przebiegu kampanii wyborczej i najważniejszych elementów programów wyborczych głównych partii politycznych. W kolejnej części przeanalizowane zostały wyniki wyborów, a ostatnia poświęcona została następstwom wyborów.

\section{Ordynacja wyborcza}

Republika Federalna Niemiec od początku uczestniczyła w tworzeniu zrębów Wspólnoty Europejskiej - od 1952 r. jako członek Europejskiej Wspólnoty Węgla i Stali (EWWiS) RFN miała 18 przedstawicieli we Wspólnym Zgromadzeniu EWWiS, a od 1958 r. zachodnie Niemcy były członkiem współzałożycielem Europejskiej Wspólnoty Gospodarczej (EWG) i Europejskiej Wspólnoty Energii Atomowej (Euratom). Za oficjalną datę powstania Parlamentu Europejskiego uznaje się rok 1958, kiedy weszły w życie postanowienia traktatów rzymskich, a wszystkie trzy wspólnoty otrzymały jeden wspólny organ parlamentarny (od 1962) - Parlament Europejski. Przez pierwsze lata istnienia Parlamentu Europejskiego jego członkowie byli delegowani przez parlamenty państw członkowskich. Dopiero od czasu pierwszych wyborów z czerwca $1979 \mathrm{r}$. posłowie do Parlamentu Europejskiego wybierani są w ogólnoeuropejskich wyborach bezpośrednich, przy czym opierających się o narodowe ordynacje wyborcze. Wybory w Niemczech odbywają się w oparciu o wielokrotnie nowelizowaną ordynację wyborczą z 16 czerwca 1978 r. (Gesetz über die Wahl der Abgeordneten, 1978-2013). Początkowo w RFN wybierano 81 przedstawicieli do PE (w tym trzech reprezentantów Berlina Zachodniego), a po zjednoczeniu Niemiec liczba wybieranych posłów wzrosła do 99 (począwszy od wyborów w 1994 r.). W wyniku zapisów poczynionych w Traktacie lizbońskim liczba posłów wybieranych z Niemiec uległa zmniejszeniu z 99 do 96, co zostało zaaprobowane decyzją Bundestagu (Bundesgesetzblatt, 2013, Teil 1, s. 3749). W RFN do wyborów z 2009 r. włącznie obowiązywała pięcioprocentowa klauzula zaporowa, a głosy na mandaty przeliczano, na początku wykorzystując metodę d'Hondta, od 1989 r. metodę Hare'a-Niemeyera, a od 2009 r. posługując się metodą Sainte-Laguë. Inaczej niż w wyborach do Bundestagu (gdzie niemiecki wyborca dysponuje dwoma głosami) wyborca oddaje tutaj tylko jeden głos, a partie mogą wystawiać swe listy wyborcze dla obszaru całych Niemiec, jak i dla poszczególnych krajów federacji. $Z$ perspektywy niemieckich partii politycznych istotny jest również fakt, że otrzymują one częściowe finansowanie swej działalności wynikającej z Ustawy Zasadniczej w oparciu o wyniki uzyskane w wyborach do Bundestagu, do Parlamentu Europejskiego oraz do parlamentów krajowych. W wypadku wyborów do Parlamentu Europejskiego wsparcie ze strony państwa otrzymują te partie, które uzyskały co najmniej $0,5 \%$ głosów w ostatnich wyborach do PE (§ 18, ust. 4 Ustawy o partiach politycznych).

Parlament Europejski przez długie lata cieszył się niewielkim zainteresowaniem w Republice Federalnej Niemiec. Nieprzypadkowo przypomina się często popularne w latach 70-tych powiedzenie: „Masz dziadka, wyślij go do Europy” (Hast du einen 
Opa, schick ihn nach Europa), kiedy Parlament Europejski był miejscem, do którego odsyłano polityków będących na politycznej emeryturze (Książniakiewicz, 2014). Jednak wraz ze wzrostem roli i uprawnień Parlamentu Europejskiego w procesie legislacyjnym wspólnoty europejskiej (Traktat z Maastricht, Traktat amsterdamski, Traktat lizboński) zmieniał się stosunek niemieckich partii politycznych do tej instytucji. Coraz więcej uwagi przykładano do odpowiedniego doboru kandydatów. Inaczej niż w Polsce, gdzie wśród kandydatów do obsady mandatu poselskiego w Parlamencie Europejskim często pojawiali się ludzie znani i popularni, niemieckie partie na swych listach wyborczych starały się umieszczać nie tyle ludzi popularnych, ile obeznanych w sprawach europejskich. Nie szło to jednak w parze ze wzrostem zainteresowania Niemców wyborami do Parlamentu Europejskiego, które w latach 1979-1994 odbywały się przy dość wysokiej jak na warunki europejskie frekwencji na poziomie ok. $60 \%$, by po wyborach z 1999 r. spaść do poziomu 43-45\% (zob. tabela 1). Niemniej frekwencja wyborcza w wyborach do Parlamentu Europejskiego w Niemczech była zdecydowanie niższa od frekwencji podczas wyborów do Bundestagu, ale również ustępowała wyraźnie przeciętnej frekwencji w wyborach do parlamentów krajowych. Tym samym dla niemieckiego wyborcy wybory do Parlamentu Europejskiego stały na trzecim miejscu pod względem ważności. Tak niska pozycja w hierarchii wyborów elekcji do Parlamentu Europejskiego stała u podstaw koncepcji zaliczających wybory do Parlamentu Europejskiego do grona drugorzędnych - podobnie jak wyborów do parlamentów krajowych $-\mathrm{z}$ perspektywy narodowej (nationale Nebenwahl) w stosunku do wyborów parlamentarnych (Hauptwahl), w wypadku RFN wyborów do Bundestagu, gdzie rozstrzyga się o składzie reprezentacji parlamentarnej i pośrednio kształcie przyszłego rządu narodowego (Niedermayer, 2014; Schmitt, Sanz, Braun, 2009, s. 485). Oskar Niedermayer, odnosząc się do teorii wyborów drugorzędnych, zwrócił uwagę na fakt, że wybory do Parlamentu Europejskiego cieszą się mniejszym zainteresowaniem zarówno ze strony wyborców, mediów, jak i samych partii, aniżeli wybory do Bundestagu, czy nawet wybory do parlamentów krajowych. Postawił równocześnie kilka hipotez wyjaśniających przyczyny takiego stanu rzeczy. Drugorzędne znaczenie wyborów do Parlamentu Europejskiego z perspektywy niemieckich wyborców wynika z faktu, że nie dostrzegają oni bezpośredniego przełożenia wyników wyborów na skład parlamentu i kształt przyszłego rządu jak w wyborach do Bundestagu i parlamentów krajowych. Wyborcy traktują z mniejszym zainteresowaniem wybory europejskie również dlatego, że decyzje Parlamentu Europejskiego postrzegają oni jako mniej istotne od decyzji podejmowanych przez Parlament Federalny (Bundestag). Niska frekwencja wyborcza nie wynika z negatywnego nastawienia obywateli do samej instytucji Parlamentu Europejskiego, lecz jest następstwem niewielkiego wpływu decyzji PE na życie codzienne obywateli. W czasie wyborów europejskich kwestie polityki wewnętrznej mają większy wpływ na decyzje wyborców niż sprawy europejskie. Tym samym wybory do Parlamentu Europejskiego stały się drugorzędnymi wyborami z perspektywy narodowej i zostały zdominowane przez sprawy wewnętrzne, a partie i media traktują je przede wszystkim jako kolejny test popularności partii na gruncie krajowym. O. Niedermayer zwrócił uwagę również na fakt, że w wyborach do Parlamentu Europejskiego partie eurosceptyczne mają większe szanse na sukces niż w wyborach do Bundestagu. Partie $\mathrm{z}$ lewego i prawego marginesu sceny politycznej są z reguły bardziej sceptyczne wobec 
Unii Europejskiej niż partie środka i stanowią istotną alternatywę dla niechętnej idei wspólnoty europejskiej części społeczeństwa niemieckiego. Oczekuje się również, że partie mniejsze w wyborach do Parlamentu Europejskiego będą uzyskiwały większe poparcie niż w wyborach do Bundestagu, również ze względu na fakt uniknięcia strategicznego głosowania części wyborców pod konkretną koalicję. Partie polityczne traktują wybory do Parlamentu Europejskiego jako mniej ważne i w czasie kampanii wyborczej nie poruszają tak istotnych kwestii jak przed wyborami do Bundestagu, gdyż zorientowane są przede wszystkim na płaszczyznę narodową (Niedermayer, 2014, s. 524-526).

Tabela 1

Wyniki niemieckich wyborów do Parlamentu Europejskiego w latach 1979-2009

\begin{tabular}{|c|c|c|c|c|c|c|c|c|c|c|c|c|c|c|}
\hline \multirow{2}{*}{ Pybortia } & \multicolumn{2}{|c|}{1979} & \multicolumn{2}{|c|}{1984} & \multicolumn{2}{|c|}{1989} & \multicolumn{2}{|c|}{1994} & \multicolumn{2}{|c|}{1999} & \multicolumn{2}{|c|}{2004} & \multicolumn{2}{|c|}{2009} \\
\hline & $\%$ & M. & $\%$ & M. & $\%$ & M. & $\%$ & M. & $\%$ & M. & $\%$ & M. & $\%$ & M. \\
\hline $\mathrm{CDU} / \mathrm{CSU}$ & 49,2 & 42 & 45,9 & 41 & 37,8 & 32 & 38,8 & 47 & 48,7 & 53 & 44,5 & 49 & 37,9 & 42 \\
\hline SPD & 40,8 & 35 & 37,4 & 33 & 37,3 & 31 & 32,2 & 40 & 30,7 & 33 & 21,5 & 23 & 20,8 & 23 \\
\hline FDP & 6,0 & 4 & 4,8 & - & 5,6 & 4 & 4,1 & - & 3,0 & - & 6,1 & 7 & 11,0 & 12 \\
\hline S90/Zieloni & 3,2 & - & 8,2 & 7 & 8,4 & 8 & 10,1 & 12 & 6,4 & 7 & 11,9 & 13 & 12,1 & 14 \\
\hline PDS/Linke & - & - & - & - & - & - & 4,7 & - & 5,8 & 6 & 6,1 & 7 & 7,5 & 8 \\
\hline REP & - & - & - & - & 7,1 & 6 & 3,9 & - & 1,7 & - & 1,9 & - & 1,3 & - \\
\hline Pozostałe & 0,8 & - & 3,7 & - & 3,8 & - & 6,2 & - & 3,7 & - & 8,0 & - & 9,3 & - \\
\hline Łącznie & & 81 & & 81 & & 81 & & 99 & & 99 & & 99 & & 99 \\
\hline
\end{tabular}

Frekwencja wyborcza: 1979 r. $-65,7 \%, 1984$ r. $-56,8 \%, 1989$ r. $-62,3 \%, 1994$ r. $-60,0 \%, 1999$ r. $-45,2 \%, 2004$ r. $-43,0 \%, 2009$ r. $-43,3 \%$.

Źródło: http://www.wahlrecht.de/ergebnisse/europa.htm.

Niemieckie wybory do Parlamentu Europejskiego z 25 maja 2014 r. były wyjątkowe ze względu na zniesienie progu wyborczego. W odniesieniu do analizy przebiegu niemieckich wyborów do Parlamentu Europejskiego z 7 czerwca 2009 r. Federalny Trybunał Konstytucyjny wypowiedział się w orzeczeniu z 9 listopada 2011 r. o niekorzystnym wpływie 5-procentowego progu wyborczego z punktu widzenia zapisów konstytucyjnych i nakazał jego zmianę. 13 czerwcu 2013 r. Bundestag głosami CDU/CSU, SPD, FDP i Sojuszu 90/Zielonych uchwalił nowelizację ustawy wyborczej do PE obniżając próg wyborczy z poziomu 5\% na 3\%. Znowelizowana ustawa weszła w życie na początku października 2013 r. (Bundesgesetzblatt, 2013, Teil 1, s. 3749), lecz została zaskarżona przez mniejsze ugrupowania (m.in. Partię Piratów, NPD, FW i ÖDP) i osoby prywatne (ok. 1000 wniosków) do Federalnego Trybunału Konstytucyjnego, które zaskarżyły ją ze względu na nierówność szans (Bundesverfassungsgericht prüft Drei-Prozent-Hürde, 2013). 26 lutego 2014 r. Federalny Trybunał Konstytucyjny (stosunkiem głosów 5 do 3) uznał zasadność skarg drobnych ugrupowań i nakazał całkowite zniesienie progu wyborczego w wyznaczonych na 25 maja 2014 r. niemieckich wyborach do Parlamentu Europejskiego. W uzasadnieniu wyroku zwrócono uwagę m.in. na fakt, że w wyborach do Parlamentu Europejskiego nie chodzi o utworzenie rządu i powołanie stabilnej koalicji rządowej jak w wypadku wyborów do Bundestagu, lecz istotniejsze jest oddanie rzeczywistych preferencji wyborczych obywateli. Dzięki 
temu przed drobnymi partiami, które nie miałyby szans na przekroczenie progu wyborczego, otworzyła się możliwość wejścia do Parlamentu Europejskiego (Wyrok FTK z 26.02.2014; Haug, 2014).

\section{Kampania wyborcza}

3 marca 2014 r. upłynął w Niemczech termin zgłaszania list wyborczych przed wyborami do Parlamentu Europejskiego. Swoje listy dla obszaru całych Niemiec zgłosiły 42 ugrupowania. CDU tradycyjnie zgłosiła swe listy krajowe we wszystkich 15 krajach federacji z wyjątkiem Bawarii, zaś CSU wystawiła swą listę krajową w Bawarii. Federalna Komisja Wyborcza (Bundeswahlausschuss) na otwartym posiedzeniu 15 marca 2014 r. pozytywnie zweryfikowała 25 list wyborczych z zastrzeżeniem propozycji CDU/CSU (tym samym wyborca w każdym kraju federacji mógł dokonywać wyboru spośród 24 list wyborczych). W wyborach wystartowało 1053 kandydatów (w tym 327 kobiet) ubiegających się o 96 mandatów eurodeputowanych, reprezentujących 25 partii i związków politycznych (Komunikaty prasowe federalnego kierownika wyborczego, 2014 a, 2014b, 2014c).

Większość niemieckich partii politycznych jeszcze przed ogłoszeniem decyzji Federalnej Komisji Wyborczej rozpoczęła wstępną fazę swych kampanii wyborczych, prezentując swych czołowych kandydatów na listach wyborczych, jak również programy wyborcze. Już 19 stycznia 2014 r. FDP uchwaliła swój program wyborczy i wybrała Alexandra Grafa Lambsdorffa liderem listy wyborczej FDP w Niemczech (przewodniczącym frakcji Porozumienia Liberałów i Demokratów na rzecz Europy, ALDE, jest belgijski polityk Guy Verhofstadt). CSU ustaliła swą listę krajową 25 stycznia, a na jej czele znalazł się Markus Ferber. Sam program wyborczy CSU przyjęty został oficjalnie dopiero 10 maja. Również 25 stycznia 2014 r. AfD wybrała swego przewodniczącego (Sprecher) Bernda Lucke jako czołowego kandydata na partyjnej liście wyborczej, jednocześnie ogłaszając swój program przed wyborami do PE. 26 stycznia 2014 r. delegaci SPD na zjazd partii w Berlinie przyjęli program wyborczy partii i wybrali dotychczasowego przewodniczącego Parlamentu Europejskiego Martina Schulza czołowym kandydatem SPD w wyborach do Parlamentu Europejskiego (przy poparciu 97,3\% delegatów). Działacze Sojuszu 90/Zielonych na zjeździe partii w dniach 7-9 lutego 2014 r. przyjęli program wyborczy i wybrali liderów listy wyborczej partii: Rebeccę Harms i Svena Giegolda. Die Linke ogłosiła swój program 15/16 lutego na zjeździe partii w Hamburgu i wybrała Gabi Zimmer (przewodniczącą frakcji Die Linke w EP i byłą przewodniczącą partii) czołową kandydatką partii w wyborach do Parlamentu Europejskiego. Jako ostatnia spośród znaczących partii wyboru swego czołowego kandydata dokonała CDU. Podczas kongresu partii w Berlinie (5 kwietnia 2014 r.) delegaci CDU wybrali byłego premiera Dolnej Saksonii Davida McAllistera czołowym kandydatem partii (przy poparciu 97\% delegatów), a jednocześnie przyjęli program wyborczy partii. Niespełna miesiąc wcześniej, 7 marca podczas kongresu Europejskiej Partii Ludowej, europejscy chrześcijańscy demokraci wybrali premiera Luksemburga Jeana-Claude Junckera czołowym kandydatem całej europejskiej chadecji w wyborach do Parlamentu Europejskiego (Niedermayer, 2014, s. 529, 530). 
Kampania wyborcza przed wyborami do Parlamentu Europejskiego wyznaczonymi na 25 maja 2014 r. toczyła się w Niemczech w zupełnie innych warunkach, aniżeli kampania przed poprzednimi wyborami w 2009 r., lecz podobnie jak 5 lat wcześniej akcenty wewnątrzniemieckie przeważały nad tematami europejskimi. Zarówno w 2009 r., jak i w 2014 r., u władzy w Niemczech była wielka koalicja CDU/CSU-SPD kanclerz Angeli Merkel. Jednak wybory z 7 czerwca 2009 r. poprzedzały wybory do Bundestagu (które odbyły się nieco ponad trzy i pół miesiące później, 27 września 2009 r.), a kampania wyborcza przed wyborami do Parlamentu Europejskiego stanowiła wstęp do kampanii wyborczej przed wyborami do Bundestagu. Równocześnie współpraca chadecji i SPD w ramach wielkiej koalicji pod koniec XVI kadencji Bundestagu stawała się coraz trudniejsza, a w czasie kampanii wyborczej obydwa najsilniejsze ugrupowania stosowały wobec siebie dość agresywną kampanię, zdając sobie sprawę, że po wyborach do Bundestagu nie utworzą wspólnej koalicji. Szczególnie tyczyło się to SPD, która w obliczu kryzysu partii, starała się zrzucić ze swych barków odpowiedzialność za trudną sytuację wewnętrzną. A kampania wyborcza w Niemczech w 2009 r. zdominowana była przez walkę ze skutkami światowego kryzysu na rynkach finansowych, a na gruncie wewnętrznym dominowały takie tematy jak kwestia ratowania pogrążonych w kryzysie przedsiębiorstw jak Opel i sieć handlowa Karstadt. W czasie kampanii SPD profilowała się jako przeciwnik neoliberalnej gospodarki i obrońca zagrożonych utratą miejsc pracy pracobiorców. W 2014 r. sytuacja w Niemczech wyglądała inaczej. Sprawy europejskie w latach 2009-2014 zdominowane były przez walkę z kryzysem zadłużenia w państwach strefy euro, jak również debatą nad sposobami zażegnania kryzysu i przyszłością Unii Europejskiej. Sytuacja gospodarcza Niemiec na tle pogrążonych w kryzysie gospodarek państw strefy euro, zwłaszcza z południa Europy, prezentowała się korzystnie. Niemniej sprzeciw znacznej części społeczeństwa niemieckiego wzbudzał fakt ratowania kosztem niemieckiego podatnika upadających gospodarek Gracji, Cypru i innych pogrążonych w kryzysie państw strefy euro. Tym razem wybory do Parlamentu Europejskiego odbywały się osiem miesięcy po wyborach do Bundestagu XVIII kadencji (22 września 2013 r.) i pięć miesięcy od czasu sformowania nowej wielkiej koalicji CDU/CSU-SPD kanclerz Angeli Merkel (17 grudnia 2013 r.). Sytuacja ta determinowała w znacznym stopniu sposób prowadzenia kampanii wyborczej przed wyborami do Parlamentu Europejskiego przez partie koalicji rządzącej. Liderzy głównych partii, zwłaszcza CDU i SPD, starali się unikać bezpośrednich konfrontacji w czasie kampanii wyborczej, aby nie zaburzać prac nowego rządu. Z drugiej strony politycy partii koalicyjnych starali się przekonać wyborców wykazując swą skuteczność poprzez szybką realizację partyjnych propozycji zapisanych w umowie koalicyjnej jak np. kwestia ustawowego wprowadzenia płacy minimalnej dla całych Niemiec (propozycja SPD). Dotyczyło to zwłaszcza skrzydłowych partii koalicyjnych - SPD i CSU - które nadawały dynamikę pracom nowego rządu, zdając sobie sprawę, że może to mieć przełożenie na ich wyniki w zbliżających się wyborach do Parlamentu Europejskiego. Kanclerz Angeli Merkel w szczególności zależało na spoistości koalicji, niemniej w toku kampanii nie udało się uniknąć tarć na linii CSU-SPD. Dotyczyło to zwłaszcza polityki imigracyjnej rządu, krytykowanej przez CSU. Na początku maja 2014 r. Markus Ferber, czołowy kandydat CSU do Parlamentu Europejskiego, zaatakował Martina Schulza lidera listy SPD a zarazem przewodni- 
czącego Parlamentu Europejskiego, podkreślając, że pochodzi wprawdzie z Niemiec, ale jego głos wywodzi się raczej z zadłużonych krajów południa Europy (Schuldenländern). M. Ferber krytykował go równocześnie za to, że po tragedii koło Lampedusy w październiku 2013 r. powiedział, że każdy Afrykanin, który osiagnie europejską ziemię powinien być serdecznie witany w Unii Europejskiej. Określił przy tym nawet M. Schulza mianem „kierownika band przemytników” (Geschäftsführer der Schleppenbanden). Krytykę ze strony CSU kierownictwo SPD potrafiło umiejętnie wykorzystać, akcentując lewicowy profil własnej partii w ramach wielkiej koalicji (Jacobsen, 2014; Kubiak, 2014, s. 2,3). Ważnym tematem w czasie kampanii wyborczej była sytuacja na Ukrainie. Die Linke obarczyła rząd federalny częściową odpowiedzialnością za eskalację napięcia na Ukrainie, jednocześnie protestując przeciwko oskarżaniu strony rosyjskiej za eskalowanie napięcia. Takie stanowisko nie przyniosło Die Linke żadnych korzyści, doprowadziło jedynie do wzrostu napięcia na linii SPD-Die Linke (Niedermayer, 2014, s. 532). Kwestia ukraińska stała się tematem jednego z najgłośniejszych wystapień w czasie kampanii wyborczej. Chodzi o emocjonalne przemówienie ministra spraw zagranicznych Franka Waltera Steinmeiera z 19 maja 2014 r., kiedy wystapił z ostrą repliką wobec grupki zwolenników polityki rosyjskiej na Ukrainie zakłócających wiec wyborczy SPD w Berlinie. Samo przemówienie, które zostało opublikowane na serwisie youtube, w krótkim czasie obejrzało ponad 2 miliony internautów (https://www.youtube.com/watch?v=AX5m5swD-QU).

Kampania wyborcza przed wyborami do Parlamentu Europejskiego nie cieszyła się tak wielkim zainteresowaniem wyborców, jak kampania przed wyborami do Bundestagu w 2013 r. Świadczy o tym m.in. niska oglądalność pierwszej debaty telewizyjnej pomiędzy liderami obu największych frakcji w Parlamencie Europejskim (Jean-Claude Juncker i Martin Schulz) transmitowanej 8 maja 2014 r. przez telewizję ZDF, którą oglądało jedynie 1,8 miliona telewidzów, co stanowiło zaledwie 5,8\% ogółu telewidzów (Niedermayer, 2014, s. 535, 536). Tymczasem debatę pomiędzy Angelą Merkel (CDU) i Peerem Steinbrückiem (SPD), kandydatami największych partii do fotela kanclerskiego, oglądało 1 września 2013 r. na antenach ARD, ZDF, RTL, ProSieben i Phoenix łącznie 17,7 milionów widzów (Maier, Faas, Maier, 2014, s. 38). Dziesięć dni przed wyborami europejskimi jedynie $40 \%$ Niemców było zainteresowanych udziałem w wyborach (w porównaniu do $67 \%$ zainteresowanych wyborami do Bundestagu we wrześniu 2013 r.) (Forschungsgruppe Wahlen, 2014, s. 2). Teza Oskara Niedermayera o większym wpływie spraw wewnętrznych od europejskich na decyzje wyborców w czasie wyborów do Parlamentu Europejskiego znajduje potwierdzenie w badaniach ośrodka Forschungsgruppe Wahlen z Mannheim, według których dla 56\% głosujących Niemców ważniejsze przy decyzji o wyborze konkretnej partii były sprawy niemieckie, a dla 40\% polityka europejska (Forschungsgruppe Wahlen, 2014, s. 1). Nie dziwi zatem fakt, że w czasie kampanii wyborczej dominowały przede wszystkim sprawy niemieckie, ważniejsze z punktu widzenia typowego niemieckiego wyborcy. Niemniej kwestie europejskie znalazły swoje ważne miejsce w programach partii politycznych. Większość znaczących niemieckich partii politycznych opowiadała się za pogłębieniem demokratyzacji Unii Europejskiej, m.in. w oparciu o wprowadzenie prawa inicjatywy dla Parlamentu Europejskiego. Wychodząc z tego założenia CDU, CSU, FDP i Sojusz 90/Zieloni domagały się zmniejszenia roli Komisji Europejskiej, a CDU 
postulowała bezpośredni wybór przez obywateli Przewodniczącego Komisji Europejskiej, zaś CSU, Die Linke i FDP postulowały wprowadzenie w Unii Europejskiej instytucji referendów narodowych. $\mathrm{Z}$ drugiej strony AfD postulowała wzmocnienie roli narodowych parlamentów w ramach Unii. W kwestii unii bankowej CDU, SPD, FDP i Zieloni oceniały ją pozytywnie. AfD ją odrzucała, postulując aby nadzór nad bankami pozostał w gestii władz poszczególnych państw członkowskich. Die Linke wzywała do nacjonalizacji banków. CSU i FDP domagały się możliwości występowania krajów ze strefy euro, a AfD domagała się jej rozwiązania, lub co najmniej nowego uformowania i ograniczenia (bez udziału państw południowej Europy). Za możliwością dalszego rozszerzenia Unii Europejskiej wypowiadały się SPD, Sojusz 90/Zieloni, Die Linke i FDP, opowiadając się za szerokimi negocjacjami z Turcją z perspektywą przyjęcia Turcji do Unii Europejskiej na pełnych prawach członkowskich. Praktycznie wszystkie większe niemieckie partie przyjęły w swych programach stanowisko proeuropejskie, z mniejszymi lub większymi (Die Linke, CSU) zastrzeżeniami. Eurosceptyczna AfD, choć nie odrzucała samej idei Unii Europejskiej, domagała się jej reformy w oparciu o wzmocnienia wpływów parlamentów narodowych, a także wzywała do rozwiązania lub dogłębnego zreformowania strefy euro. Tradycyjnie negatywną wobec instytucji Unii Europejskiej kampanię wyborczą prowadziła skrajnie prawicowa NPD (Niedermayer, 2014, s. 530, 531; Książniakiewicz, 2014, s. 3, 4).

\section{Wyniki wyborów}

W przeprowadzonych 25 maja 2014 r. niemieckich wyborach do Parlamentu Europejskiego wzięło udział 29843798 wyborców, co stanowiło 48,1\% uprawnionych do głosowania. Pozytywnie należy odebrać wzrost frekwencji wyborczej w porównaniu do wyborów z 2009 r. aż o 4,8 p.p. (w 2009 r. frekwencja w wyborach do Parlamentu Europejskiego wyniosła w RFN 43,3\%). Frekwencja wyborcza w Niemczech plasowała się powyżej średniej w całej Unii Europejskiej (43,09\%), przy czym daleko było Niemcom do frekwencji uzyskanej w Belgii i Luksemburgu (ok. 90\%), czy też na Malcie $(74,8 \%)$ i we Włoszech $(60 \%)$. Na drugim biegunie znalazły się Słowacja (13\%) i Czechy (19,5\%).

Tabela 2

Oficjalne wyniki wyborów do Parlamentu Europejskiego w Niemczech z 25 maja 2014 r. wraz z zestawieniem wyników z 2009 r.

\begin{tabular}{||c|c|c|c|c|c|c||}
\hline \multirow{2}{*}{ Partia } & \multicolumn{3}{|c|}{ Wybory z 2014 r. } & \multicolumn{2}{c||}{ Wybory z 2009 r. } & \multirow{2}{*}{$\begin{array}{c}\text { Różnica } \\
\text { (p.p.) }\end{array}$} \\
\cline { 2 - 6 } & glosy & $\mathbf{\%}$ & mandaty & \% & mandaty & 7 \\
\hline CDU & 2 & 3 & 4 & 5 & 6 & $-0,7$ \\
\hline SPD & 8812653 & 30,0 & 29 & 30,7 & 34 & 6,5 \\
\hline S90/Zieloni & 8003628 & 27,3 & 27 & 20,8 & 23 & $-1,4$ \\
\hline Die Linke & 2139274 & 10,7 & 11 & 12,1 & 14 & 0,1 \\
\hline AgD & 2168455 & 7,4 & 7 & 7,5 & 8 & 7,1 \\
\hline CSU & 15674014 & 7,1 & 7 & - & - & $-1,9$ \\
\hline
\end{tabular}




\begin{tabular}{|l|c|c|c|c|c|c||}
\hline \multicolumn{1}{|c|}{1} & 2 & 3 & 4 & 5 & 6 & 7 \\
\hline FDP & 986841 & 3,4 & 3 & 11,0 & 12 & $-7,6$ \\
\hline FW & 428800 & 1,5 & 1 & 1,7 & - & $-0,2$ \\
\hline P. Piratów & 425044 & 1,4 & 1 & 0,9 & - & 0,5 \\
\hline Tierschutzpartei & 366598 & 1,2 & 1 & 1,1 & - & 0,1 \\
\hline NPD & 301139 & 1,0 & 1 & - & - & 1,0 \\
\hline Familie & 202803 & 0,7 & 1 & 1,0 & - & $-0,3$ \\
\hline ÖDP & 185244 & 0,6 & 1 & 0,5 & - & 0,1 \\
\hline Die PARTEI & 184709 & 0,6 & 1 & - & - & 0,6 \\
\hline REP & 109757 & 0,4 & - & 1,3 & - & $-0,9$ \\
\hline Volksabstim. & 88535 & 0,3 & - & 0,3 & - & 0,0 \\
\hline BP & 62438 & 0,2 & - & 0,2 & - & 0,0 \\
\hline PBC & 55336 & 0,2 & - & 0,3 & - & $-0,1$ \\
\hline Pro NRW & 52649 & 0,2 & - & - & - & 0,2 \\
\hline AUF & 50953 & 0,2 & - & 0,1 & - & 0,1 \\
\hline CM & 30136 & 0,1 & - & 0,2 & - & $-0,1$ \\
\hline DKP & 25147 & 0,1 & - & 0,1 & - & 0,0 \\
\hline MLPD & 18198 & 0,1 & - & - & - & 0,1 \\
\hline BüSo & 10369 & 0,0 & - & 0,0 & - & 0,0 \\
\hline PSG & 8924 & - & - & 0,0 & - & 0,0 \\
\hline Pozostałe & - & - & - & 3,1 & - & $-3,1$ \\
\hline \hline
\end{tabular}

Uprawnione do głosowania: 61998824 osoby, głosowało: 29843798 osób, frekwencja wyborcza: 48,1\%.

Źródło: Oficjalne wyniki wyborów podane na stronie federalnego kierownika wyborczego. http://www.bundeswahlleiter.de/de/europawahlen/EU_BUND_14/ergebnisse/bundesergebnisse/index.html.

W niemieckich wyborach do Parlamentu Europejskiego każdorazowo zwycięstwo odnosiły partie chadeckie. Nie inaczej było tym razem. W wyborach z 25 maja $2014 \mathrm{r}$. na 15 list krajowych CDU padło nieco ponad 30\% głosów, a na listę krajową CSU w Bawarii padło 5,3\% głosów w skali całych Niemiec. Łączne poparcie dla partii chadeckich wyniosło niespełna $35,4 \%$ i było niższe o $2,5 \%$ od poparcia uzyskanego w poprzednich wyborach do Parlamentu Europejskiego, przy czym spadek poparcia dotknął przede wszystkim CSU. Na kiepskie notowania CSU złożył się zarówno spadek poparcia w samej Bawarii, gdzie na CSU głosowało 40,5\% wyborców (o 7,5 p.p. mniej niż 5 lat wcześniej), jak również niższa frekwencja w tymże kraju federacji wynosząca 40,8\% (wobec 42,3\% w 2009 r.). CSU, jako partia najbardziej dystansująca się wobec Unii Europejskiej spośród partii wielkiej koalicji, prowadziła w Bawarii dość krytyczną wobec Unii kampanię wyborczą, licytując się na tym polu z miejscową AfD (która w Bawarii uzyskała 8,1\% głosów). Spiritus movens takiej kampanii był przewodniczący CSU i zarazem premier Bawarii Horst Seehofer, który wziął odpowiedzialność za słaby wynik swojej partii w wyborach (Schäffer, 2014). Tym razem nie powiódł się tradycyjny „szpagat” CSU pomiędzy krytyką instytucji europejskich u siebie w Bawarii, a formalnym poparciem dla polityki europejskiej pokazywanym na zewnątrz (Huber, 2014; Nonnenmachen, 2014). Politykę taką realizowała CSU m.in. w latach 90-tych, gdy premier Bawarii Edmund Stoiber lansował w swym kraju krytyczny wobec Unii kurs, podczas gdy federalny minister finansów z ramienia CSU 
Theo Waigel aktywnie działał na rzecz wprowadzenia wspólnej waluty. Znaczny wzrost poparcia (o 6,5 p.p.) w stosunku do wyborów z 2009 r. odnotowała SPD, która uzyskała 27,3\% głosów. W 2009 r. socjaldemokraci znajdowali się w głębokim kryzysie, stąd wzrost poparcia nie może dziwić. Dla SPD istotny był również fakt, że wybory do Parlamentu Europejskiego przyniosły partii lepszy wynik niż wybory do Bundestagu z 22 września 2013 r., a wejście do wielkiej koalicji z partiami chadeckimi nie odbiło się negatywnie (przynajmniej po pięciu miesiącach istnienia wielkiej koalicji) na wyniku SPD. Dzięki korzystnemu wynikowi w wyborach do Parlamentu Europejskiego pozycja SPD w ramach wielkiej koalicji uległa wzmocnieniu. Co ważne, partii udało się zaakcentować swój lewicowy profil w ramach wielkiej koalicji, jak również ukazać wyborcom swój zdecydowanie proeuropejski kurs. Nie bez znaczenia na korzystny wynik SPD miał również fakt relatywnie wysokiej rozpoznawalności w społeczeństwie niemieckim Martina Schulza, czołowego kandydata SPD. Największe poparcie spośród partii średnich uzyskał Sojusz 90/Zieloni. Na partię Zielonych reprezentującą wyraźny kurs proeuropejski oddało swój głos 10,7\% wyborców $(-1,4$ p.p. w stosunku do wyborów w 2009 r.). Poparcie dla Die Linke w wyborach do Parlamentu Europejskiego utrzymało się praktycznie na tym samym poziomie co w 2009 r. $(7,4 \%$, spadek o 0,1 p.p.). Ogromny sukces w majowych wyborach do Parlamentu Europejskiego odniosła eurosceptyczna AfD. Po 15 miesiącach od powstania nowa partia uzyskała 7\% poparcia i 7 mandatów do Parlamentu Europejskiego. Gdyby wzorem poprzednich wyborów utrzymany został 5-procentowy prób wyborczy, tylko te partie reprezentowałyby RFN w Parlamencie Europejskim. Dzięki zniesieniu progu wyborczego liczba partii, które zdołały uzyskać mandat deputowanego uległa podwojeniu. Wielkim przegranym wyborów okazała się FDP, która uzyskała zaledwie 3,4\% głosów i tylko dzięki zniesieniu progu wyborczego udało się liberałom wydelegować trzech przedstawicieli do PE. W porównaniu do wyborów z 2009 r. liberałowie ponieśli największe straty spośród wszystkich partii politycznych w Niemczech $(-7,6$ p.p.). Wyniki wyborów do Parlamentu Europejskiego są kolejnym dowodem na to, że po 2010 r. FDP znalazła się w głębokim kryzysie. Choć liberałom nie zawsze udawało się przekroczyć granicę progu wyborczego (np. w 1984, 1994 i 1999 r. nie dostali się do $\mathrm{PE}$ ), to ich sytuacja w obrębie niemieckiego systemu partyjnego była o wiele korzystniejsza niż w 2014 r., choćby dlatego, że FDP cały czas posiadała swą reprezentację w Bundestagu. Całkowite zniesienie progu wyborczego przyniosło korzyści siedmiu niewielkim ugrupowaniom, którym udało się przekroczyć $0,5 \%$ poparcia i uzyskać po jednym mandacie w Parlamencie Europejskim. W grupie tej znalazły się następujące ugrupowania: Wolni Wyborcy (Freie Wähler - FW) - 1,5\% poparcia, Partia Piratów (Piratenpartei Deutschland) - 1,4\%, Partia Ochrony Zwierząt (Partei Mensch Umwelt Tierschutz - skrót Tierschutzpartei) - 1,2\%, Narodowodemokratyczna Partia Niemiec (Nationaldemokratische Partei Deutschlands - NPD) - 1\%, Partia Rodziny (Familien-Partei Deutschlands - skrót Familie) - 0,7\%, Partia Ekologiczno-Demokratyczna (Ökologisch-Demokratische Partei - ÖDP) - 0,6\% oraz Partia na rzecz Pracy, Praworządności, Ochrony Zwierząt, Promocji Elit i Inicjatyw Oddolnej Demokracji, w skrócie Die PARTEI (Partei für Arbeit, Rechtsstaat, Tierschutz, Elitenförderung und basisdemokratische Initiative) - 0,6\%. W gronie siedmiu posłów wydelegowanych przez drobne ugrupowania znalazł się jeden przedstawiciel NPD, partii od lat propa- 
gującej hasła zdecydowanie antyunijne, jak również reprezentant Die PARTEI, partii o dość specyficznym profilu, parodiującej tradycyjne partie polityczne. Aby uzyskać jeden mandat w wyborach do Parlamentu Europejskiego z Niemiec po zniesieniu progu wyborczego wystarczyło otrzymać około 185 tys. głosów, co stanowiło nieco ponad 0,5\% poparcia (Kubiak, 2014).

\section{Konsekwencje wyborów}

Wyniki niemieckich wyborów do Parlamentu Europejskiego zostały przyjęte przez prasę niemiecką pozytywnie. $Z$ jednej strony podkreślano wzrost frekwencji wyborczej, z drugiej zwracano uwagę na sukces eurosceptyków z AfD. Niemniej wyniki wyborów „mieściły się w ramach oczekiwań i nie będą przyczyną zawirowań w niemieckiej polityce wewnętrznej” (Nonnenmachen, 2014). W komentarzach zwracano uwagę na fakt, że niemieckie wybory, w przeciwieństwie do wyborów we Francji czy Wielkiej Brytanii, przyniosły zwycięstwo partiom reprezentującym zdecydowanie proeuropejski kurs i w znacznym stopniu zaprzeczyły ogólnoeuropejskiemu trendowi objawiającemu się wyraźnym wzrostem poparcia dla ugrupowań eurokrytycznych. Partie zdecydowanie proeuropejskie uzyskały w Niemczech ponad $75 \%$ poparcia. W obliczu znacznie większego udziału w nowym Parlamencie Europejskim posłów reprezentujących krytyczne stanowisko wobec Unii Europejskiej, niemiecka reprezentacja jawi się jako swego rodzaju oaza stabilności, w zdecydowanej większości reprezentująca kurs proeuropejski. Oznacza to, że większość Niemców opowiedziała się w wyborach za kontynuowaniem dotychczasowego kursu w polityce europejskiej reprezentowanego przez główne siły polityczne.

Sukces AfD został odebrany z pewnym spokojem, w pewnym sensie dlatego, że wyniki sondażowe przewidywały sukces partii eurosceptyków. Powstała w lutym $2013 \mathrm{r}$. partia za główny cel postawiła sobie odniesienie sukcesu w wyborach do Parlamentu Europejskiego i cel ten osiągnęła. W komentarzach zwracano uwagę na fakt, że Alternatywa dla Niemiec reprezentuje przede wszystkim część społeczeństwa niemieckiego domagającą się zwiększenia wpływu państw narodowych w Unii Europejskiej oraz niechętną wobec obecnej polityki w strefie euro. W ciągu kilkunastu miesięcy od swego powstania AfD przekształciła się z partii jednego tematu domagającej się radykalnych zmian w ramach strefy euro i powrotu walut narodowych w partię o profilu narodowo-konserwatywnym. Równocześnie AfD zdołała się skonsolidować na niemieckiej scenie politycznej. Pod wpływem przewodniczącego partii B. Lucke AfD w Parlamencie Europejskim weszła w skład frakcji Europejskich Konserwatystów i Reformatorów (ECR), choć część działaczy partii optowała za przyłączeniem się do frakcji Europa Wolności i Demokracji Bezpośredniej (EFDD) (Lachmann, 2014; Bender, 2014).

Zniesienie decyzją Federalnego Trybunału Konstytucyjnego progu wyborczego w wyborach do Parlamentu Europejskiego w Niemczech przyniosło wprawdzie wysoką reprezentatywność wybranych posłów do Parlamentu Europejskiego (na ugrupowania, których posłowie dostali się do Parlamentu Europejskiego oddano ponad 98\% głosów), lecz równocześnie doszło do znacznej fragmentaryzacji reprezentacji nie- 
mieckiej w Parlamencie Europejskim. Z Niemiec do Parlamentu Europejskiego dostali się posłowie reprezentujący 14 partii politycznych (CDU i CSU liczone osobno), z tego aż siedem z nich uzyskało po jednym mandacie. Niemniej samo zniesienie progu wyborczego nie wpłynęło na istotny wzrost poparcia dla drobnych ugrupowań, które uzyskały z reguły porównywalne wyniki do wyborów z 2009 r.

Wyniki wyborów do Parlamentu Europejskiego w Niemczech stanowią, obok wyników wyborów do Bundestagu z 22 września 2013 r., kolejne potwierdzenie zmian zachodzących w obrębie niemieckiego systemu partyjnego. Z jednej strony po raz kolejny potwierdzona została pozycja chadecji jako największej siły politycznej w RFN, wzrosło poparcie dla SPD, której udało się wyjść z kryzysu lat 2008/2009, ustabilizowała się pozycja dwóch partii średnich - Sojuszu 90/Zielonych i Die Linke. Równocześnie doszło do znacznej utraty wpływów przez liberałów z FDP, a ich miejsce zajęła AfD, która coraz silniej stabilizuje się na niemieckiej scenie politycznej. Tym samym utrwalony został trend objawiający się poprzez utratę poparcia przez FDP i wzrost zaufania do AfD.

\section{Bibliografia}

Bender J. (2014), Willkommen bei den Gemäßigten, „Frankfurter Allgemeine Zeitung”, 27.05.2014, s. 5.

Bundesverfassungsgericht prüft Drei-Prozent-Hürde, ,Zeit-Online”, 18.12.2013, http://www.zeit.de/news/ 2013-12/18/prozesse-karlsruhe-verhandelt-ueber-drei-prozent-huerde-bei-europawahl-18151012.

Forschungsgruppe Wahlen (2014), Europawahl vom 25. Mai 2014, http://www.forschungsgruppe.de/Wahlen/Wahlanalysen/Newsl_Euro_2014_1.pdf.

Gesetz über die Wahl der Abgeordneten des Europäischen Parlaments aus der Bundesrepublik Deutschland (EuWG), http://www.gesetze-im-internet.de/bundesrecht/euwg/gesamt.pdf.

Haug V. (2014), Muss wirklich jeder ins Europäische Parlament? Kritische Anmerkungen zur Sperrklausel-Rechtsprechung aus Karlsruhe, ,Zeitschrift für Parlamentsfragen”, nr 2, s. 467-487.

Huber E. (2014), „,Die Zeit der einsamen Ansagen ist vorbei”, „Der Spiegel”, nr 23, 2.06.2014, s. $26-28$.

Jacobsen L. (2014), Endlich wieder streiten, „Zeit-Online”, 12.05.2014, http://www.zeit.de/politik/deutschland/2014-05/europawahl-spd-csu-cdu-gabriel-schulz.

Komunikat prasowy federalnego kierownika wyborczego z 4 marca 2014 r. (2014a), http://www.bundeswahlleiter.de/de/europawahlen/EU_BUND_14/presse/w14004_Wahlvorschlaege.html.

Komunikat prasowy federalnego kierownika wyborczego z 17 marca 2014 r. (2014b), http://www.bundeswahlleiter.de/de/europawahlen/EU_BUND_14/presse/w14006_bwa_entscheidung.html.

Komunikat prasowy federalnego kierownika wyborczego z 16 kwietnia 2014 r. (2014c), http://www.bundeswahlleiter.de/de/europawahlen/EU_BUND_14/presse/w14012_Anzahl_Kandidaten.html.

Koszel B. (2011), Niemcy wobec kryzysu finansowego strefy euro państw Unii Europejskiej, „Rocznik Integracji Europejskiej”, nr 5, s. 111-128.

Książniakiewicz M. (2014), Niemieckie wybory do Parlamentu Europejskiego. „,Masz dziadka, wyślij go do Europy”, „Biuletyn Niemiecki” nr 48, http://fwpn.org.pl/assets/Publikacje/Biuletyn_Niemiecki/BIULETYN_NIEMIECKI_NR_48.pdf. 
Kubiak P. (2014), Wybory do Parlamentu Europejskiego w Niemczech-komentarz do wyników, „Biuletyn Instytutu Zachodniego", nr 165.

Lachmann G. (2014), AfD will in Fraktion der Europäischen Konservativen, „Die Welt”, 27.05.2014, s. 4.

Maier J., Faas T., Maier M. (2014), Aufgeholt, aber nicht aufgeschlossen: Wahrnehmungen und Wirkungen von TV Duellen am Beispiel von Angela Merkel und Peer Steinbrück 2013, „Zeitschrift für Parlamentsfragen", nr 1, s. 38.

Nonnenmachen G. (2014), Keine Experimente, „Frankfurter Allgemeine Zeitung”, 26.05.2014, s. 1.

Schäffer A. (2014), Seehofer präsentiert sich selbst als Schuldigen, „Frankfurter Allgemeine Zeitung”, 27.05.2014, s. 5.

Schmitt H., Sanz A., Braun D. (2009), Motive individuellen Wahlverhaltens in Nebenwahlen. Eine theoretische und empirische Überprüfung, w: Wahlen und Wähler. Analysen aus Anlass der Bundestagswahl 2005, red. O. W. Gabriel, B. Weßels, J. W. Falter, Wiesbaden, s. 585-605.

Ustawa o partiach politycznych z 24 lipca 1967 r. (w formie z 1994 r. wraz z poprawkami z 2011 r.): http://bundesrecht.juris.de/bundesrecht/partg/gesamt.pdf.

Wyrok Federalnego Trybunatu Konstytucyjnego z 22 lutego 2014 (Wyrok FTK z 26.02.2014), https://www.bundesverfassungsgericht.de/entscheidungen/es20140226_2bve000213.html.

\section{Streszczenie}

Prezentowany artykuł poświęcony został analizie niemieckich wyborów do Parlamentu Europejskiego. Wyniki wyborów do PE w Niemczech nie przyniosły zaskakujących rozstrzygnięć. Zwyciężyły partie chadeckie przed SPD, a na dalszych miejscach znalazły się partie średnie - Sojusz 90/Zieloni i Die Linke. Istotny sukces odniosła eurosceptyczna Alternatywa dla Niemiec (AfD), a druzgocącą klęskę poniosła liberalna FDP. Wyniki wyborów w Niemczech, w przeciwieństwie do wielu krajów europejskich jak Francja i Wielka Brytania, przyniosły sukces partiom zdecydowanie proeuropejskim, które zdobyły ponad 75\% poparcia. Oznacza to akceptację zdecydowanej większości Niemców dla dotychczasowego kursu w polityce europejskiej reprezentowanego przez główne siły polityczne. Istotnym novum było zniesienie progu wyborczego, które skutkowało znacznym rozdrobnieniem niemieckiej reprezentacji w Parlamencie Europejskim (14 partii) i pozwoliło siedmiu drobnym partiom na wydelegowanie po jednym przedstawicielu do Parlamentu Europejskiego. Likwidacja progu wyborczego nie wpłynęła jednak na wzrost poparcia dla drobnych ugrupowań.

Słowa kluczowe: Niemcy, Parlament Europejski, wybory, Alternatywa dla Niemiec

\section{Elections to the European Parliament (25 May, 2014) - analysis and consequences}

\section{Summary}

The paper is concerned with the analysis of the European elections in Germany. Their results did not bring about any major surprises. The Christian Democrats won, with the Social Democrats coming second, while subsequent places were taken by the mid-sized parties, i.e., the Green Party and Die Linke. The eurosceptic Alternative for Germany (AfD) proved highly successful, while the liberal FDP suffered a crushing defeat. In contrast to many other European countries, 
such as for instance France or Great Britain, the German elections brought victory to decisively pro-European parties, which gained over $75 \%$ of the votes cast. This seems tantamount to the acceptance by a majority of Germans of the present course of European politics taken by the main political forces. One clear innovation in the elections involved the abandonment of the electoral threshold, which resulted in a major fragmentation of German MEPs, who now come from 14 different parties - including seven small parties to place a single representative in the European Parliament. The elimination of the threshold did not result in a change in the overall level of support for small parties, though.

Keywords: Germany, European Parliament, elections, Alternative for Germany 